\title{
Studies and Modeling for Upgrading Units for Heavy Oil Refineries
}

Salah M. Ali ${ }^{*}$, Dr. Hareth Sh. Moshref*, Saad K. Ibrahim*, Harith A. Mohammed*, Dr. Zaidoon M.

\author{
Shakor $^{* *}$, Dr. Shaker Mohmud ${ }^{* * *}$ \\ *Petroleum Research and Development Center $\backslash$ Oil Ministry $\backslash$ Iraq. \\ ${ }^{* *}$ Chemical Engineering Department $\backslash$ University of Technology $\backslash$ Iraq. \\ *** Oil Projects Company $\backslash$ Ministry of Oil $\backslash$ Iraq.
}

\section{$\underline{\text { Abstract }}$}

The primary objective of this study is to predict the optimum operating conditions required to operate an existing atmospheric distillation column to distillate heavier crude oils in same unit which designed mainly to fractionate moderate and lighter crude oils.

Detailed simulation model of atmospheric distillation column was made using Aspen Hysys V. 8.4 software. The model built depending on the data of real plant which located in Al-Daura midland refinery company at Baghdad/Iraq. The crude oils were described using the true boiling point (TBP) assays and Peng-Robinson package were used to predict thermodynamic properties. Three different types of crude oils (Kirkuk light, Basrah light and Basrah medium) were selected to identify the model validity. The simulation results agree very well with the industrial plant results. Finally the proposed model was used to predict optimum operating conditions required to distillate a blend of light and heavy Basrah crude oil with different mixing ratios. The objective of the optimization is to predict the maximum profit of the products within the required specifications. At optimum operating conditions the total yearly profit for distillation of a blend of $50 \%$ vol. light $+50 \%$ vol. heavy basrah crude oil was found to be $713.28 \mathrm{M}$.

Keywords Simulation, Optimization, Crude Oil, Atmospheric Distillation, Aspen Hysys.

\section{Introduction}

Crude oil composed of thousands of hydrocarbons varying from methane to very high molecular weight components, with varying proportions of paraffins, naphthenes, and aromatics [1]. The distillation column is main unit in a petroleum refinery which used to fractionate the crude oil into gases, light and heavy naphtha, gasoline, kerosene, diesel, and residue.

The properties of crude oils are varying making achieving the products specifications in distillation unit is difficult. Petroleum refining in Iraq face several challenges in the last few years, one of these challenges is increasing the demand to light fractions while decreasing the ratio of 
exploited light crude oils. Also varying the demand for light cuts within a year, the demand for kerosene is high in the winter while the demand for gas oil reach maximum in summer.

David et al. (2010) [6] applied Aspen Hysys for analysis of crude oil atmospheric distillation unit. They developed dynamic model combined with a suitable control configuration to study the transient behavior from a one stationary level of operation to anther when the operating conditions or products specifications are changed.

Lekan et al. (2012) [7], proposed a model to optimize the atmospheric distillation column of a crude oil. The proposed optimization model is applicable for the change in feed stock, market situations and products prices.

Akba and Umuze (2013) [9], make steady state MESH model to simulate crude oil distillation column. Their model is capable of predicting the concentrations and temperature of any component on the column trays. The model results of the concentrations and temperatures for five components compared with real data given maximum deviations of $8.33 \%$ and $6.62 \%$ respectively.

Sayed et al. (2013) [10], simulate a crude oil distillation unit using nonlinear steady-state model embedded in the Aspen Hysys V 7.3. The model optimized using sequential quadratic programming (SQP) algorithm. Profit maximization for the weekly scheduling strategy was carried out to process different crudes blended in specific proportions. By optimizing the scheduling decision at the operational level they obtained 0.89 million American dollars weekly average profit.

Yiqing et al. (2013) [11], applied ASPEN Plus to simulate and optimize the crude oil distillation unit. Particle swarm optimization (PSO) algorithm was used to obtain the optimum operating conditions of the existing distillation column with considering energy recovery and product profit. The optimized operating conditions include product yields, stripping steam flow rate and pumparound duties.

Ahmed and Ala'a (2014) [12], used Aspen Hysys V. 7.1 to simulate and optimize the naphtha stabilizer in Al-Basrah Refinery. Their optimization results proved that, it's possible to increase the $\mathrm{C} 5+$ recovery in reformate from $97 \%$ in actual unit to $99.6 \%$ by selection the optimum design variables and operating conditions.

Ali et al. (2014) [14], applied hybrid optimization algorithm which combines the Hysys simulation and genetic algorithm (GA) optimization method written by Matlab to optimize the design variables of the atmospheric crude oil distillation column.

Dhallia et al. (2014) [13], used Aspen Hysys to study the effect of trays number, feed tray location and reflux ratio on residue and naphtha yield. They observe that the naphtha yield decrease with 
increasing the trays number and reflux ratio. The naphtha yield also increase and residue yield decrease if the feed stage moved up in the column.

Shankar et al. (2015) [4], simulate of a real crude plant using Aspen Hysys. Experimental and simulated true boiling point for kerosene, light gas oil and atmospheric residue were taken into account in analysis of the crude distillation unit.

Most of previous studies include applying simulation results to optimize operating conditions of atmospheric distillation column. This study is important because it include simulation and optimization of whole atmospheric distillation unit which include furnace, atmospheric distillation column, naphtha stabilizer and naphtha separator.

The purpose of this study is to simulate and optimize a new crude oil distillation unit which is finally located in midland Al-Daura refinery using Aspen Hysys V. 8.4 software and compare the simulation results with real results for distillation light and medium crude oils (Kirkuk light, Basrah light and Basrah Medium) to validate the model. Also use the validated model to optimize the operating conditions required to distillate a blend of light and heavy Basrah crude oil with different blending ratios.

\section{Case Study}

The crude oil distillation unit described in this study was originally designed for fractionation of 70000 BPD of Kirkuk light, Basrah light and Basrah medium crude oils. The obtained products are LPG, Light and heavy Naphtha, Kerosene, Light Gas Oil, Heavy Gas Oil and Atmospheric Residue. The atmospheric distillation column consists of 46 tray with a total condenser, three side-strippers and two pump-arounds. The tray numbers arranged from top 1 to bottom 46.

The furnace is used to heat the crude oil to desired temperature $\left(341-345{ }^{\circ} \mathrm{C}\right)$, then the crude oil is pumped to the atmospheric distillation column at the tray 42 . The column operates with pressure 1$1.6 \mathrm{~kg} / \mathrm{cm}^{2}(\mathrm{~g})$ and total condensation. The side-strippers which used to separate kerosene, gasoline and light gas oil contains 4, 5 and 8 trays respectively. Two pump-arounds are used to provide internal reflux at various sections of the column. Overflash 5.0 vol. \% is used in order to reach sufficient fractionation efficiency. Naphtha leaves column to naphtha stabilizer to separate the gases from whole naphtha which then separated to light and heavy naphtha in the second distillation column of 35 tray [2]. 


\section{Process simulation}

Process modelling and simulation enables the designer to explore the process behaviour and select the optimum operating conditions to operate the process with maximum products at low cost. Simulation can save a lot of money and time also it is cheaper and much faster than making a series of experiments [3]. Aspen Hysys is a powerful tool for chemical processes modelling, simulation and optimization. Aspen Hysys can be use for both steady state and dynamic simulation of complex crude oil distillation system [4].

The crude oil refineries are complex, non-linear and integrated system. A rigorous distillation model includes solving equilibrium, mass and energy equations to calculate the temperatures, flow rates and compositions within the distillation column. For simulation of atmospheric crude oil distillation unit Apsen Hysys was usually used. The first step for a successful simulation is correct choice of the thermodynamic model that will be used in the calculations of the vapour-liquid properties. The Peng-Robinson equation of state is normally accepted for the compounds in the crude distillation unit. The second step is the characterization of crude oil and input data design and operating conditions. Before any calculation, the pump-arounds, side-stripers feed stage location column pressure and temperature must be specified. Important parameters for the pump-around specification are; the withdraw and return stages, mass flow and temperature drop. For the sidestripers, beside product flow, specification of the steam flow and parameters, withdraw and return stages, and the number of striper stages are entered.

Figure (1) Show the flow diagram of atmospheric crude oil distillation unit were the atmospheric distillation column is described in detail as shown in figure (2) 


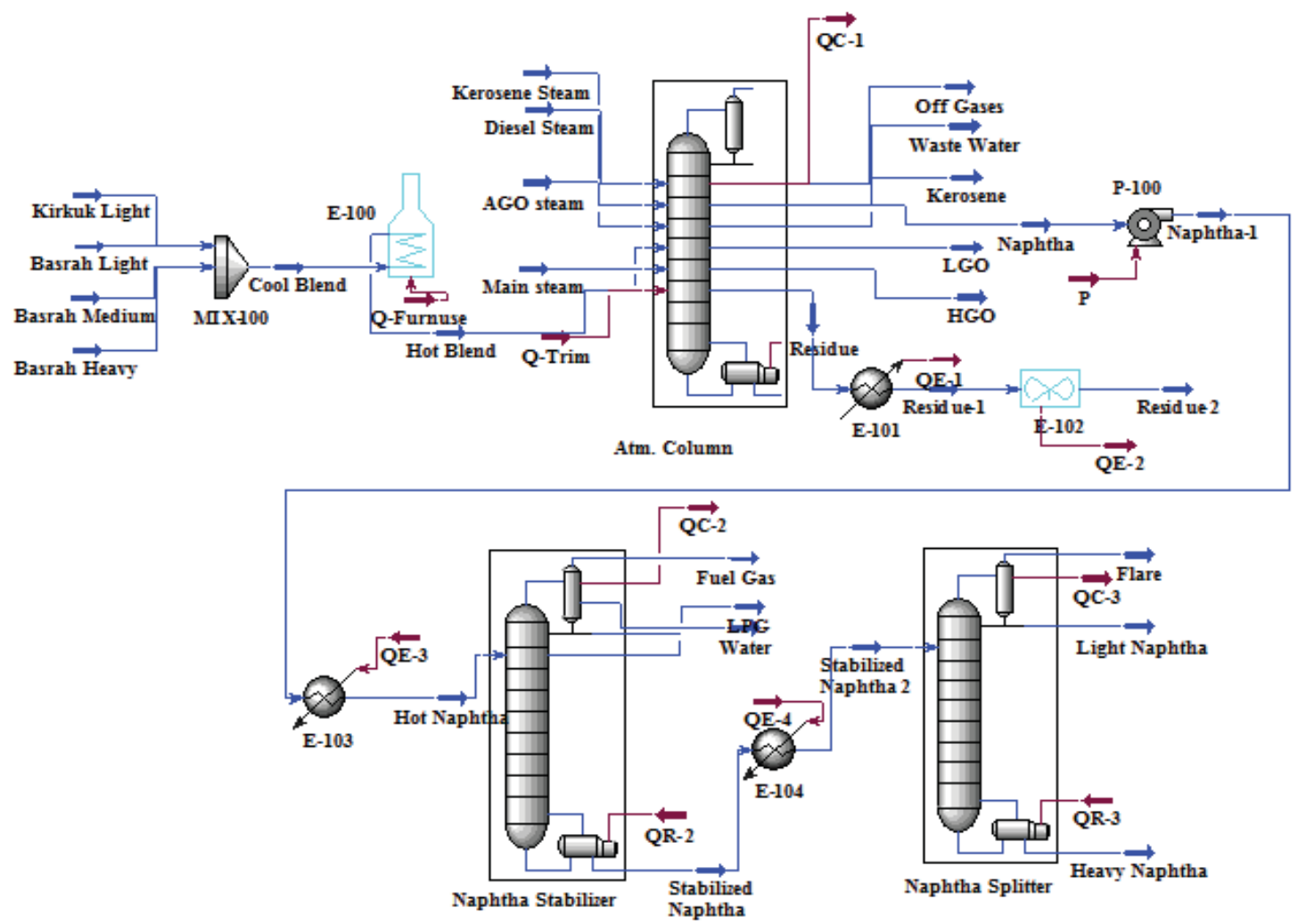

Fig. (1) Flow diagram of atmospheric crude oil distillation unit

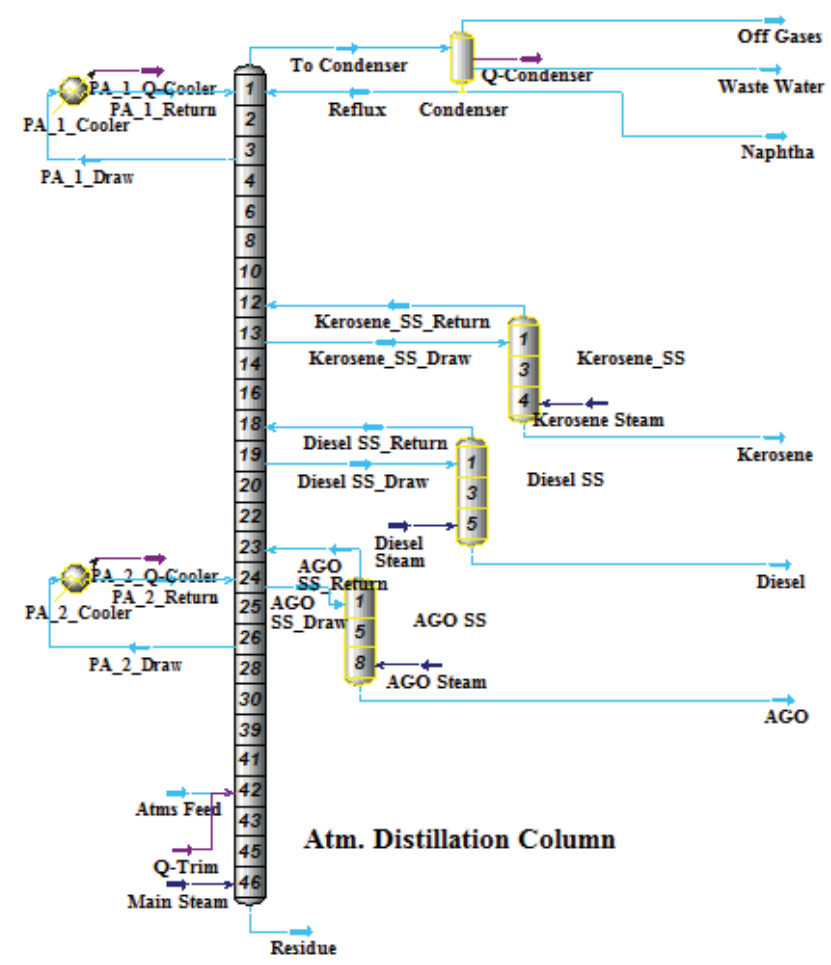

Fig. (2) Flow diagram of atmospheric crude oil distillation column 


\section{Crude Oil Properties}

Crude oils classified as light, Medium, Heavy and extra Heavy depending on API gravity ranges as shown in table (1).

Table (1) Crude oil classification according API

\begin{tabular}{|c|c|}
\hline Crude Oil & API \\
\hline Light & $30-40$ \\
\hline Medium & $22-29.9$ \\
\hline Heavy & $10-21.9$ \\
\hline Extra heavy & Minus 10 \\
\hline
\end{tabular}

API gravity is calculated as:

$$
\mathrm{API}^{\circ}=\frac{141.5}{\text { Sp. Gr. }}-131.5
$$

For any crude oil analysis the True Boiling Point (TBP) curve is essential for prediction quantities of petroleum fractions. The true boiling point curve is a plot of the boiling point of the mixture as a function of volume fraction or cumulative weight distilled. Tables (2) include the TBP assays of main four Iraqi crude oils used in this study. Table (3) represents typical crude oil cut points ${ }^{[3]}$.

Table (2) Specification of the main Iraqi crude oils $[3,5]$

\begin{tabular}{|c|c|c|c|c|c|}
\hline Crude Oil & \multicolumn{2}{|c|}{ Kirkuk Light } & Basrah Light & Basrah Medium & Basrah Heavy \\
\hline \multirow{2}{*}{ API gravity at $15.6^{\circ} \mathrm{C}$} & \multicolumn{2}{|c|}{35.8} & 33.6 & 30.5 & 23.7 \\
\hline & \multicolumn{2}{|c|}{ wt. $\%$} & wt. $\%$ & wt.\% & wt. $\%$ \\
\hline \multirow{6}{*}{ 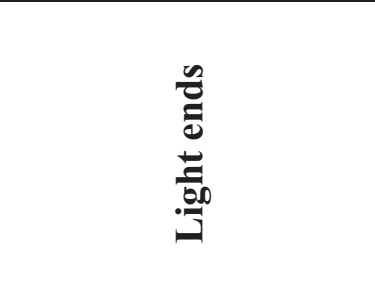 } & $\mathrm{C} 2$ & 0.01 & 0.01 & 0.01 & 0.01 \\
\hline & $\mathrm{C} 3$ & 0.16 & 0.28 & 0.36 & 0.16 \\
\hline & i-C4 & 0.31 & 0.18 & 0.19 & 0.12 \\
\hline & $\mathrm{n}-\mathrm{C} 4$ & 0.70 & 0.91 & 0.91 & 0.59 \\
\hline & i-C5 & 1.19 & 0.73 & 0.69 & 0.56 \\
\hline & $\mathrm{n}-\mathrm{C} 5$ & 1.25 & 1.25 & 0.97 & 0.85 \\
\hline \multirow{14}{*}{ 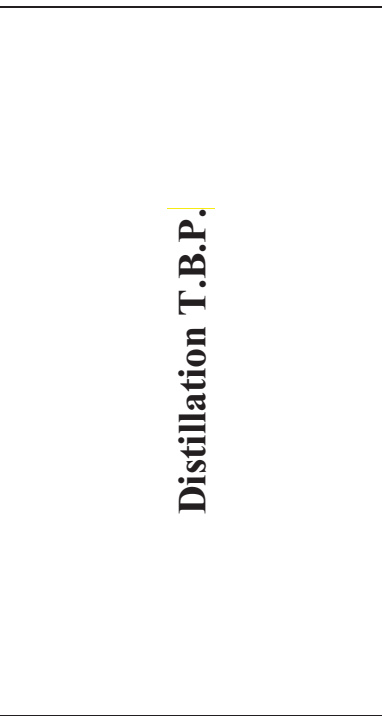 } & $50^{\circ} \mathrm{C}$ & 4.34 & 3.70 & 4.2 & 2.4 \\
\hline & $60^{\circ} \mathrm{C}$ & 5.61 & 4.00 & 5.2 & 2.5 \\
\hline & $70^{\circ} \mathrm{C}$ & 7.09 & 5.27 & 5.7 & 4.3 \\
\hline & $80^{\circ} \mathrm{C}$ & 8.35 & 6.50 & 6.8 & 4.5 \\
\hline & $100^{\circ} \mathrm{C}$ & 11.30 & 9.30 & 9.0 & 6.7 \\
\hline & $120^{\circ} \mathrm{C}$ & 14.69 & 11.50 & 13.0 & 8.5 \\
\hline & $150{ }^{\circ} \mathrm{C}$ & 19.97 & 17.00 & 16.25 & 11.7 \\
\hline & $180^{\circ} \mathrm{C}$ & 26.01 & 22.23 & 22.0 & 15.7 \\
\hline & $200{ }^{\circ} \mathrm{C}$ & 29.32 & 25.03 & 26.0 & 18.3 \\
\hline & $250^{\circ} \mathrm{C}$ & 38.85 & 34.04 & 34.0 & 25.0 \\
\hline & $300^{\circ} \mathrm{C}$ & 47.86 & 42.34 & 42.0 & 32.0 \\
\hline & $350{ }^{\circ} \mathrm{C}$ & 56.80 & 50.58 & 49.5 & 39.2 \\
\hline & $400^{\circ} \mathrm{C}$ & 64.61 & 58.15 & 53.0 & 47.4 \\
\hline & $500^{\circ} \mathrm{C}$ & 77.09 & 71.77 & 73.0 & 62.7 \\
\hline
\end{tabular}


Table (3) Typical crude oil cut points

\begin{tabular}{|l|c|c|}
\hline Cut & IBP $\left({ }^{\mathbf{0}} \mathbf{C}\right)$ & $\mathbf{E P}\left({ }^{\mathbf{}} \mathbf{C}\right)$ \\
\hline Off Gas & - & 10 \\
\hline Light Naphtha & 10 & 100 \\
\hline Heavy Naphtha & 100 & 170 \\
\hline Kerosene & 170 & 230 \\
\hline Light Gas Oil & 230 & 335 \\
\hline Heavy Gas Oil & 335 & 355 \\
\hline Atmospheric Residue & $355+$ & - \\
\hline
\end{tabular}

\section{Results and Discussion}

\subsection{Steady state simulation}

Three different crude oils were selected to provide the model validity. These crude oils are Kirkuk light, Basrah light and Basrah medium. In all three cases the tray efficiency was taken as $80 \%$. The products yield for any crude oil depends on crude oil characterization and the cut points temperatures. Figures $(3,4$, and 5) summarize a comparison between experimental and model results for Kirkuk light, Basrah light and Basrah medium crude oils respectively. From figures (3 and 4) the predicted products weight fraction for LPG, light naphtha, heavy naphtha, kerosene, light gasoil, heavy gas oil and residue agree very well with real results. Figure (5) show that for Basrah medium crude oil the predicted residue weight fraction is $49.6 \%$ while the actual weight fraction is $55.5 \%$, this error is due to variable tray efficiencies by varying crude oil characteristics. The mean percentage relative errors are 1.31, 0.95 and 1.58 for Kirkuk light, Basrah light and Basrah medium crude oils respectively. As conclusion of the simulation results, it's clear that the simulation model predicts the produces flow rates very well and within acceptable error.

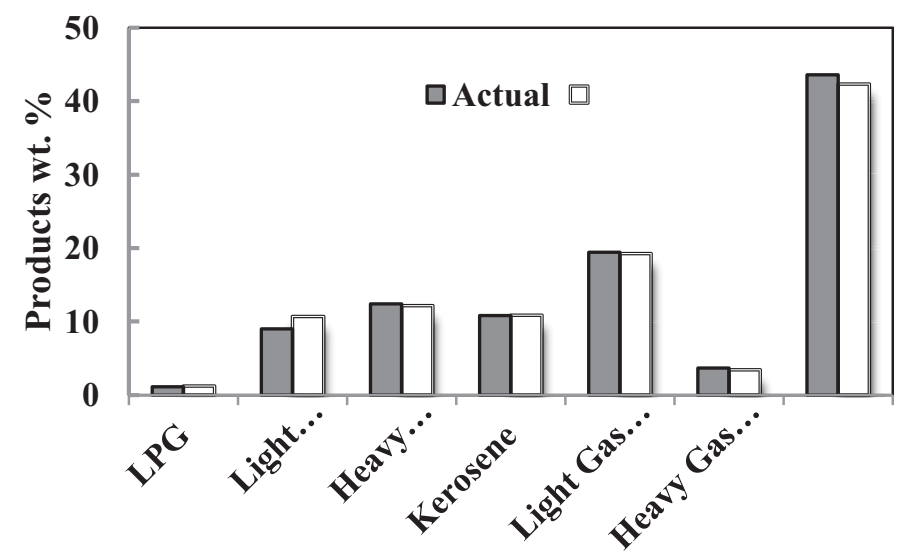

Fig. (3) Comparison between experimental and predicted products weight fraction for Kirkuk light crude oil. 


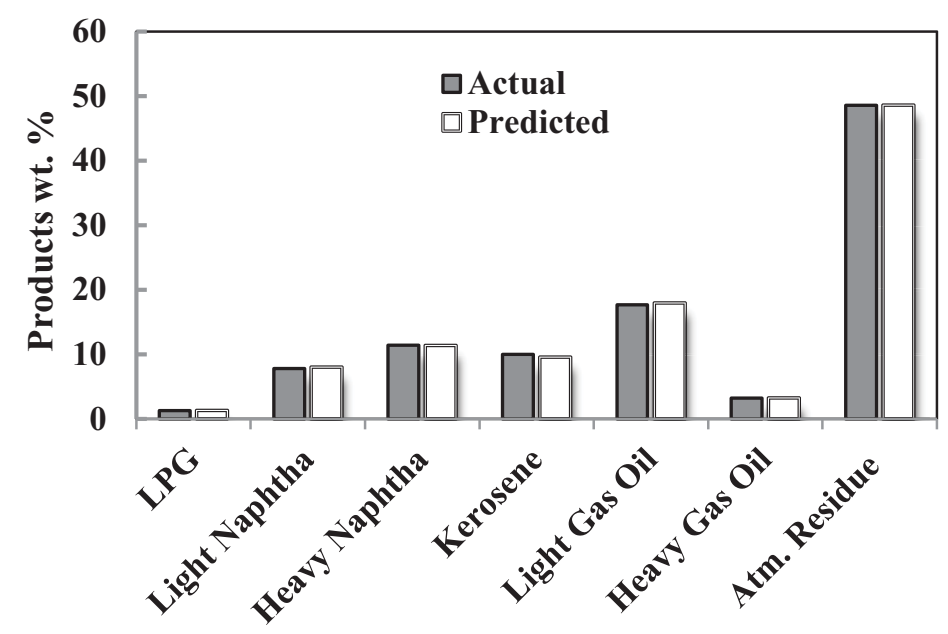

Fig. (4) Comparison between experimental and predicted products weight fraction for Basrah light crude oil.

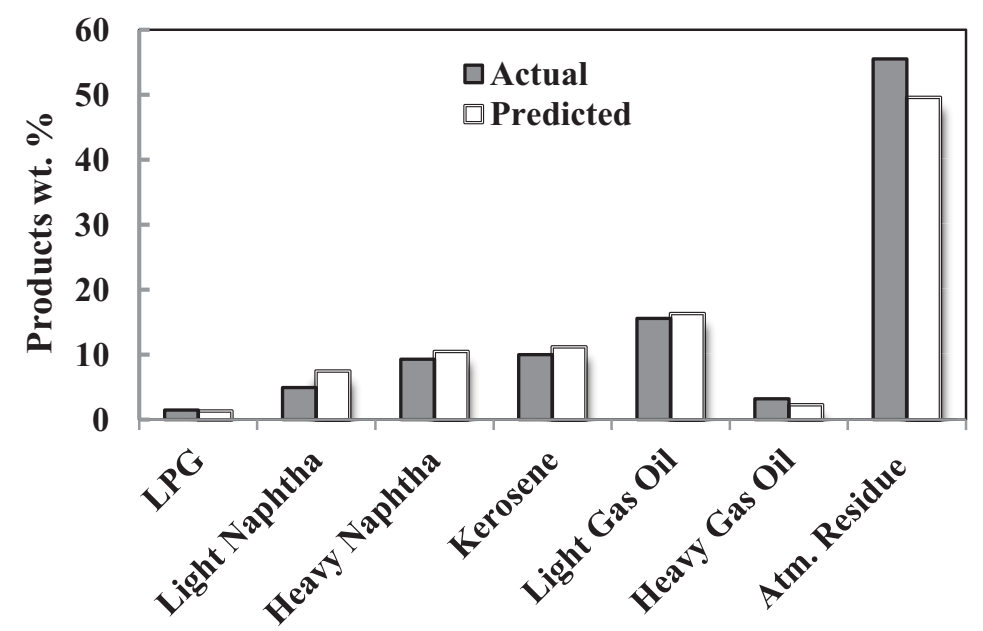

Fig. (5) Comparison between experimental and predicted products weight fraction for Basrah medium crude oil.

\subsection{Products weight fraction in Heavy Crude oil}

Blending of crude oil was used to produce a crude oil blend that has higher value than the raw heavy crude oil. Figure (6) contain evaluation of products weight fractions for both Basrah heavy crude oil compared with a blend composed of 50\% Basrah heavy $+50 \%$ Basrah light crude oils. For heavy basrah crude oil weight percent of LPG, light naphtha, heavy naphtha, kerosene, light gas oil, heavy gas oil and residue are $0.72,5.24,7.98,7.88,14.8,3.03$ and $60.36 \%$ respectively. These results show that the blending 50\% heavy Basrah crude oil with the same percent of Basrah light crude oil will increase the weight fraction of light Gas oil from $14.8 \%$ in Basrah Heavy to 16.34 in the $50 \%$ blend. 


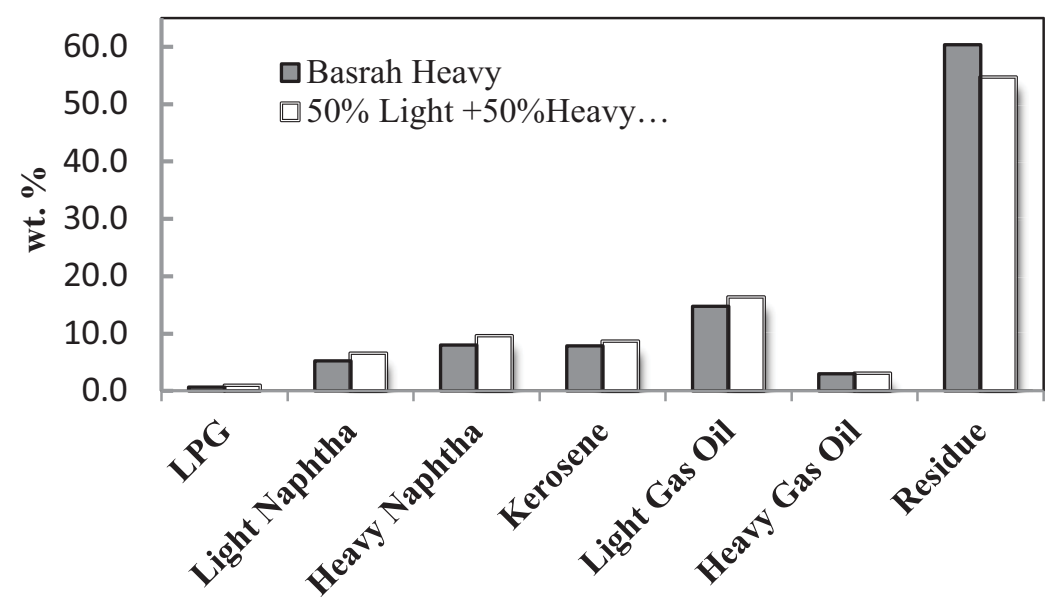

Fig. (6) Comparison between products weight fraction of Heavy Basrah comparing with $50 \%$ Light $+\mathbf{5 0 \%}$ Heavy basrah blend.

\subsection{Optimization of Operating Conditions}

Aspen Hysys software was used to study the effect of crude oil specifications and column operating conditions on the products yield. The optimization was done by using Sequential Quadratic Programming algorithm. The column operating conditions is depending mainly on the type of the crude oil. Optimization is necessary to calculate the optimum operating conditions. The objective function for the optimization process is to increase the profit. The objective function $\mathrm{f}_{\text {obj }}$ can be expressed mathematically as:

$$
F_{o b j}=\sum_{i=1}^{N_{p r o d}} P_{p r, i} F_{p r, i}-\sum_{j=1}^{N_{c r}} P_{c r, j} F_{c r, j}-\sum_{k=1}^{N_{s t}} C_{s t, k} F_{s t, k}-\sum_{m=1}^{N_{u t l i}} C_{u t i l, m} U_{u t i l, m}
$$

Ten effective variables were selected (four steam flow rates, three columns feed temperatures and three products withdrawal temperatures) as operating conditions variables to maximize total profit. Optimization was subjected to equality and inequality constraints to achieve products with specific properties by manipulating operating conditions. For kerosene, light gasoil and heavy gasoil, the range of products withdrawal temperatures was measured by the difference between the 95\% ASTM D86 distillation temperature of a lighter product and the 5\% ASTM D86 distillation temperature of an adjacent heavier product. Table (4) contains the lower and upper bounds of manipulated variables. 
Table (4) Range of manipulated variables

\begin{tabular}{|l|c|}
\hline Optimization Variables & Range \\
\hline Atmospheric distillation feed temperature $\left[{ }^{\circ} \mathrm{C}\right]$ & $340-345$ \\
\hline Naphtha stabilizer feed temperature $\left[{ }^{\circ} \mathrm{C}\right]$ & $135-140$ \\
\hline Naphtha splitter feed temperature $\left[{ }^{\circ} \mathrm{C}\right]$ & $140-145$ \\
\hline Kerosene withdrawal temperature $\left[{ }^{\circ} \mathrm{C}\right]$ & $200-210$ \\
\hline Light Gas Oil withdrawal temperature $\left[{ }^{\circ} \mathrm{C}\right]$ & $260-270$ \\
\hline Heavy Gas Oil withdrawal temperature $\left[{ }^{\circ} \mathrm{C}\right]$ & $320-330$ \\
\hline Kerosene steam flow rate $[\mathrm{kg} / \mathrm{hr}]$ & $500-1000$ \\
\hline Light Gas Oil steam flow rate $[\mathrm{kg} / \mathrm{hr}]$ & $8000-1200$ \\
\hline Heavy Gas Oil steam flow rate $[\mathrm{kg} / \mathrm{hr}]$ & $500-1000$ \\
\hline Main steam flow rate $[\mathrm{kg} / \mathrm{hr}]$ & $3000-5000$ \\
\hline
\end{tabular}

According to Iraqi market, the feed, products and utility prices are summarized in table (5). The total profit was calculated for one year of 350 working days.

Table (5) prices of feed, products and utility.

\begin{tabular}{|l|c|c|}
\hline Item & Units & Price \$ \\
\hline Crude oil & $\mathrm{m}^{3}$ & 37.24 \\
\hline Steam & $\mathrm{kg}$ & $9.27 \times 1^{-3}$ \\
\hline Cooling energy & $\mathrm{kJ} / \mathrm{hr}$ & $5 \times 1^{-6}$ \\
\hline Heating energy & $\mathrm{kJ} / \mathrm{hr}$ & $1.1 \times 1^{-5}$ \\
\hline Electricity & $\mathrm{kW} / \mathrm{hr}$ & $8.43 \times 1^{-2}$ \\
\hline LPG & $\mathrm{kg}$ & 0.52 \\
\hline Light Naphtha & $\mathrm{m}^{3}$ & 360 \\
\hline Heavy Naphtha & $\mathrm{m}^{3}$ & 340 \\
\hline Kerosene & $\mathrm{m}^{3}$ & 240 \\
\hline Light gas oil & $\mathrm{m}^{3}$ & 320 \\
\hline Heavy gas oil & $\mathrm{m}^{3}$ & 300 \\
\hline Atmospheric residue & $\mathrm{m}^{3}$ & 150 \\
\hline
\end{tabular}

Table (6) summarize the optimum operating conditions of crude oil distillation unit used to fractionate three type of 30/70 \%, 50/50 \% and 70/30 light to heavy Basrah crude oil blends, while the optimization results are shown in table (7). Changing the operating conditions within the unit 
will effect directly on heat consumption and on the total profit. It was shown from table (7), the manipulating the operating conditions increase the products profit within acceptable range without change the annual cost. The total yearly profit are 691.98, 713.28 and 724.4903 M\$ for these three blends respectively. Light crude oils produce larger quantities of light valuable cuts. Lighter crude consume more steam, cooling and heating duties. Heavier crude oil consumes more electricity for pumping and cooling fan operation. Crude oil and utilities cost represent about $23 \%$ of the products outcome.

Table (6) Optimum operating conditions at maximum profit for different blending ratios.

\begin{tabular}{|l|c|c|c|}
\hline \multirow{2}{*}{ Optimization Variable } & \multicolumn{3}{c|}{ Blend Ratio (\%Vol) } \\
\cline { 2 - 4 } & $\begin{array}{c}30 \% \text { Light } \\
70 \% \text { Heavy }\end{array}$ & $\begin{array}{c}50 \% \text { Light } \\
50 \% \text { Heavy }\end{array}$ & $\begin{array}{c}70 \% \text { Light } \\
30 \% \text { Heavy }\end{array}$ \\
\hline Atmospheric distillation feed temperature $\left[{ }^{\circ} \mathrm{C}\right]$ & 341.25 & 340.00 & 344.75 \\
\hline Naphtha stabilizer feed temperature $\left[{ }^{\circ} \mathrm{C}\right]$ & 140.00 & 139.56 & 136.28 \\
\hline Naphtha splitter feed temperature $\left[{ }^{\circ} \mathrm{C}\right]$ & 140.87 & 142.20 & 141.25 \\
\hline Kerosene withdrawal temperature $\left[{ }^{\circ} \mathrm{C}\right]$ & 206.29 & 204.60 & 200.50 \\
\hline Light Gas Oil withdrawal temperature $\left[{ }^{\circ} \mathrm{C}\right]$ & 265.81 & 265.08 & 266.75 \\
\hline Heavy Gas Oil withdrawal temperature $\left[{ }^{\circ} \mathrm{C}\right]$ & 325.83 & 324.91 & 328.50 \\
\hline Kerosene steam flow rate $[\mathrm{kg} / \mathrm{hr}]$ & 500.00 & 727.86 & 874.83 \\
\hline Light Gas Oil steam flow rate $[\mathrm{kg} / \mathrm{hr}]$ & 1044.81 & 982.00 & 1079.87 \\
\hline Heavy Gas Oil steam flow rate $[\mathrm{kg} / \mathrm{hr}]$ & 583.46 & 800.39 & 573.69 \\
\hline Main steam flow rate [kg/hr] & 4099.49 & 4049.59 & 4398.73 \\
\hline
\end{tabular}


Table (7) Optimization results at maximum profit for different blending ratios.

\begin{tabular}{|l|c|c|c|}
\hline \multirow{2}{*}{\multicolumn{1}{|c|}{ Optimization Variable }} & \multicolumn{3}{c|}{ Blend Ratio (\%Vol) } \\
\cline { 2 - 4 } & $30 \%$ Light & $50 \%$ Light & $70 \%$ Light \\
$70 \%$ Heavy & $50 \%$ Heavy & $30 \%$ Heavy \\
\hline Fuel Gas[kg/hr] & 297.23 & 247.56 & 337.84 \\
\hline LPG Gas[kg/hr] & 7714.71 & 8003.69 & 8055.37 \\
\hline Light naphtha flow rate [kg/hr] & 10424.78 & 12469.19 & 11727.75 \\
\hline Heavy naphtha flow rate [kg/hr] & 42463.74 & 47120.82 & 50946.54 \\
\hline Kerosene flow rate [kg/hr] & 39472.74 & 32444.81 & 33574.69 \\
\hline Light gas oil flow rate [kg/hr] & 56185.11 & 76113.34 & 78673.13 \\
\hline Heavy gas oil flow rate [kg/hr] & 21869.63 & 9344.08 & 9748.25 \\
\hline Atmospheric residue flow rate [kg/hr] & 236111.00 & 223728.01 & 211345.01 \\
\hline Crude oil cost [M \$/year] & 145.06 & 145.06 & 145.06 \\
\hline Steam cost [M \$/year] & 0.48 & 0.51 & 0.54 \\
\hline Electricity cost [M \$/year] & 6.87 & 6.55 & 6.23 \\
\hline Cooling cost [\$/year] & 42.87 & 42.78 & 43.69 \\
\hline Heating cost [\$/year] & 9.73 & 9.70 & 10.20 \\
\hline Products outcome [M \$/year] & 896.99 & 917.87 & 930.21 \\
\hline Total profit [M \$/year] & 691.98 & 713.28 & 724.49 \\
\hline
\end{tabular}

Figure (7) shows the simulation results for vapor and liquid flow rates along the column operated at optimum operating conditions to fractionate a blend of $50 \%$ light $+50 \%$ heavy basrah crude oil. It can be recognized that there are three peaks in vapor and liquid flow rates, two at pump-around sections and one at flash zone.

Figures (8 and 9) show the simulation results for temperature and pressure respectively along atmospheric distillation column at optimum conditions. Temperature distribution within the column subjected to products withdrawal temperatures. Maximum temperature about $345{ }^{\circ} \mathrm{C}$ is reached at crude oil flash zone. The pressure distribution was linear increase from the higher point at reboiler to the lower point at the top tray. 


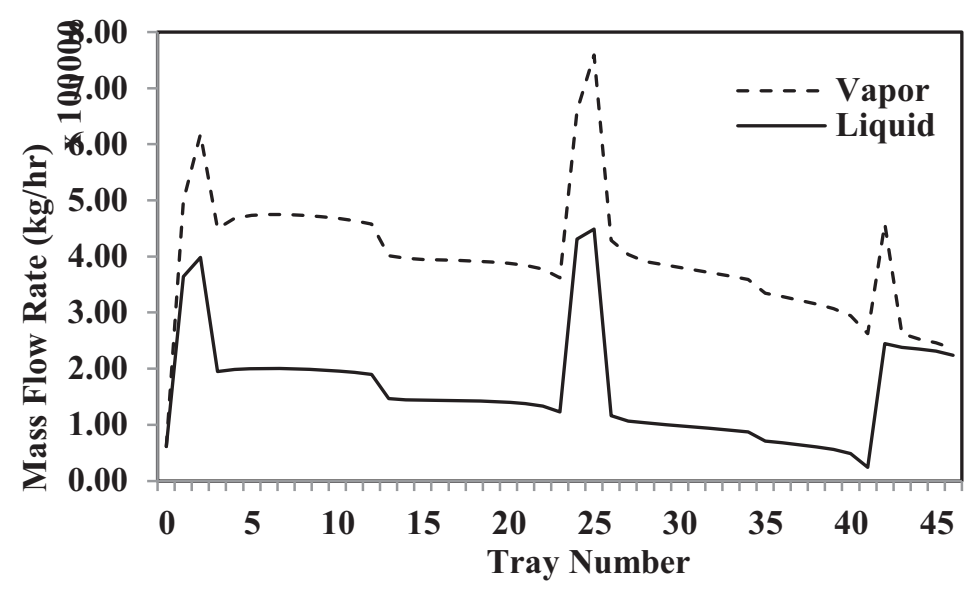

Fig. (7) Liquid and vapor flow rates with respect to tray number

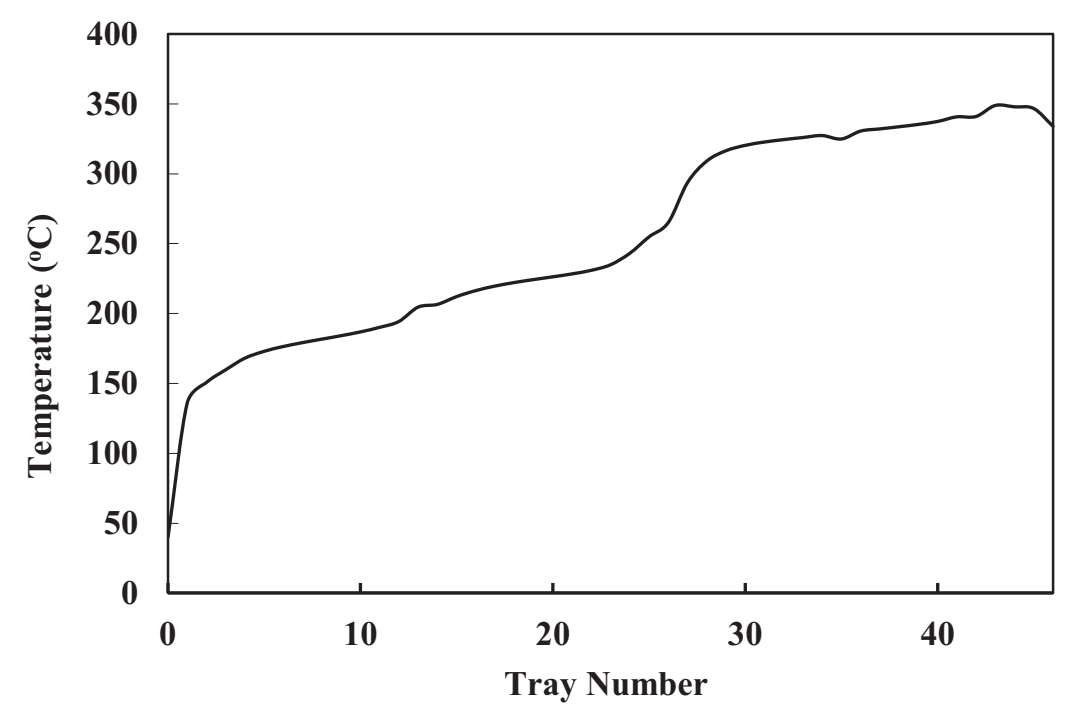

Fig. (8) Tray temperatures with respect to tray number

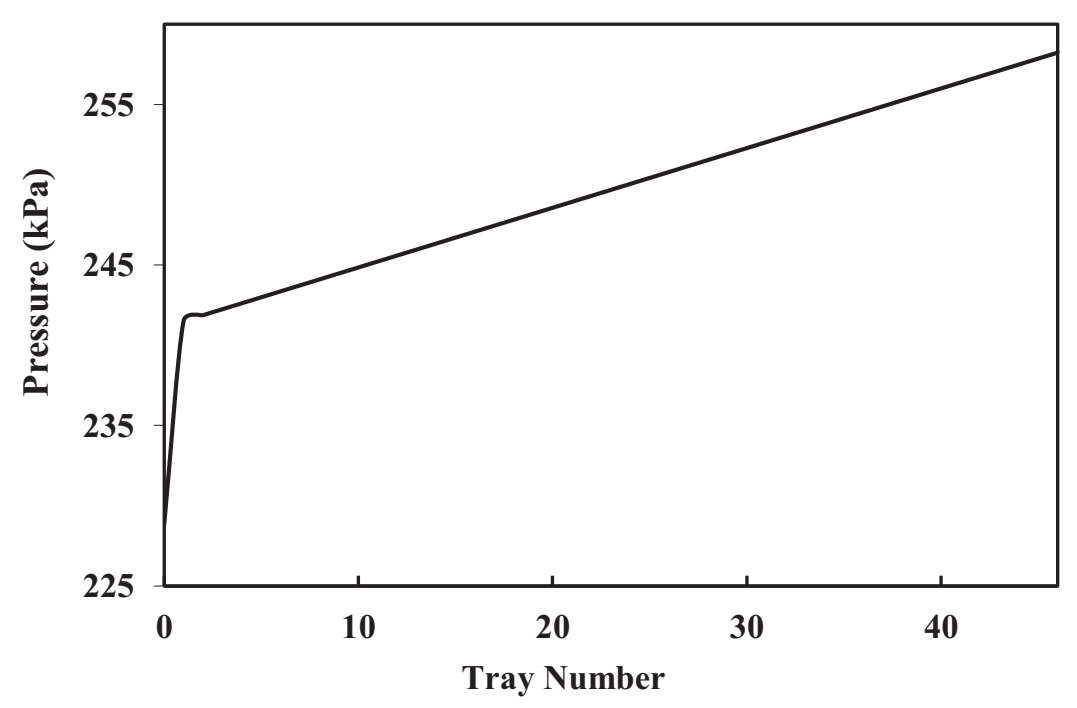

Fig. (9) Column pressure with respect to tray number 


\section{Conclusion}

For three different crude oils (Kirkuk light, Basrah light and Basrah medium), Hysys simulation results agree very well with the results of actual unit. Depending on simulation model the user could predict the effect of design and operating variable on the petroleum products quality and quantity.

By making optimization for the atmospheric distillation unit operating conditions the products with a specified quality could be achieve without changing the design of the unit equipments.

The simulation results show that the blending 50\% Basrah heavy crude oil with the same percent of Basrah light crude oil will increase the light Gas oil weight percent from $14.8 \%$ in Basrah Heavy to 16.34 in the $50 \%$ blend. Lighter crude oils consume more steam, cooling and heating energy and less electricity. The total profit of lighter crude is greater than heavier crude oils because it produces light valuable cuts more than that produced by heavier crude oils. Lighter crude consume more steam, cooling and heating duties. Heavier crude oil consumes more electricity for pumping and cooling fan operation. Crude oil and utilities cost represent about $23 \%$ of the products outcome.

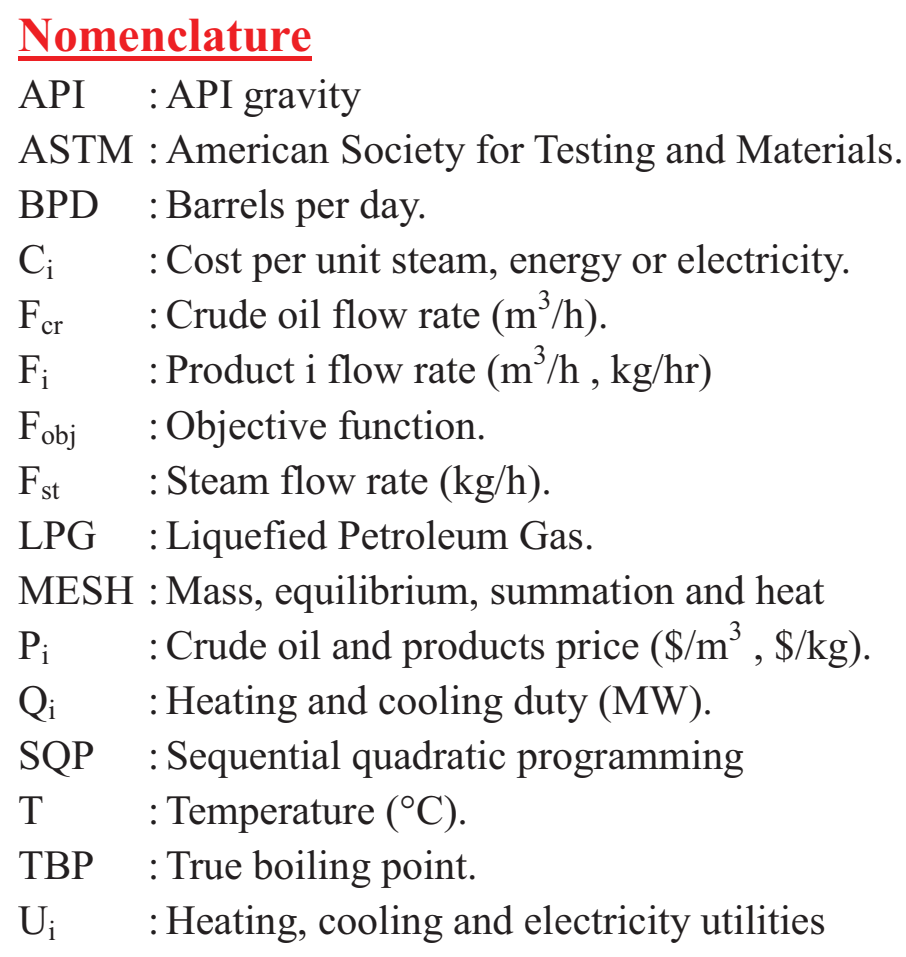




\section{$\underline{\text { References }}$}

1. Juma Haydary, Tomáš Pavlík "Steady-State and Dynamic Simulation of Crude Oil Distillation Using Aspen Plus and Aspen Dynamics", Institute of Chemical and Environmental Engineering, Faculty of Chemical and Food Technology (2009).

2. Midland Refineries Company, Al-Daura Refinery, 70000 BPSD Czechoslovakian unit operating manual.

3. Aspen-Hysys Software, 2014. Version 8.4. Aspen Tech Inc, USA.

4. Shankar N., Aneesh V. and Sivasubramanian V. "Aspen Hysys based Simulation and Analysis of Crude Distillation Unit", International Journal of Current Engineering and Technology, Vol.5, No.4 (Aug 2015).

5. British Petroleum Bp company website (www.bp.com/content/dam/bp-crudes/ en/Assays/)

6. David D. G., Fernando G. M., and Sebastião F. A., "Dynamic Simulation and Control: Application to Atmospheric Distillation Unit of Crude Oil Refinery", 20th European Symposium on Computer Aided Process Engineering - ESCAPE20, Elsevier (2010).

7. Lekan T. P., Jamiu A. A., and Solomon O. A., "Investigations into Optimization Models of Crude Oil Distillation Column in the Context of Feed Stock and Market Value", Advances in Chemical Engineering and Science, 2, pp 474-480, (2012).

8. Abdul-Halim A. M., Hadi G. A., and Hayder A. K., "The Relationships between the Physical and Chemical Properties of Narrow Fractions Distilled From Mixed Kirkuk and SharkiBaghdad Crude Oils" Iraqi Journal of Chemical and Petroleum Engineering, Vol.9, No.2,pp(1-8), 2008.

9. Akpa, J. G. and Umuse, O. D. "Simulation of a Multi-component Crude Distillation Column", American Journal of Scientific and Industrial Research, (2013).

10.Syed F. A., Nooryusmiza Y., Saibal G., Mardhati Z. A., and Khairiyah S., "Profit Maximization of a Crude Distillation Unit”, Proceedings of the 6th International Conference on Process Systems Engineering (PSE ASIA), Kuala Lumpur. (25 - 27 June 2013).

11. Yiqing L., He W., and Xigang Y. “ Simultaneous optimization for heat-integrated crude oil distillation system", 6th International Conference on Process Systems Engineering (PSE ASIA), Kuala Lumpur 25 - 27,(June 2013). 
12.Ahmed R. H. and Ala'a A. J. "Enhance $C 5^{+}$Recovery Predicting and Maximizing the Reformate Production in Naphtha Stabilizer Using HYSYS” Journal of Chemical, Biological and Physical Sciences, Vol. 4, No. 3; pp 1851-1865, (2014).

13.Dhallia, M. B. , Sumaya A. M. and Ali A. R. "Effect on naphtha and Residue Yield Through Different Operating and Design Varables in Atmospheric Distillation Column", Journal of Petroleum Tecnology and Alternative Fuels 5(4), pp 31-37, (2014).

14.Ali K. K., Ajeet K. R., and Abdulwahid A. A.," Optimizatin and Performance Evaluation of An Existing Crude Oil Distillation System”, IJARET, V 5, Issue 4, pp. 94-102, April (2014). 